\title{
PD27 - Specific antibodies in oral immunotherapy for cow's milk allergy: kinetics and prediction of clinical outcome
}

\author{
Emma M Savilahti1 ${ }^{1 *}$, Mikael Kuitunen ${ }^{1}$, Mika Mäkelä2${ }^{2}$ Erkki Savilahti ${ }^{1}$ \\ From 3rd Pediatric Allergy and Asthma Meeting (PAAM) \\ Athens, Greece. 17-19 October 2013
}

\section{Background}

Specific antibodies to cow's milk (CM) may have prognostic value in CM allergy. We hypothesized that they may also help in predicting the clinical outcome of oral immunotherapy (OIT) prior to treatment, and that changes in specific antibody levels during the therapy may reflect its efficacy.

\section{Methods}

We investigated 40 children aged 6-17 year with cow's milk allergy who either successfully completed OIT $(n=32)$ or discontinued the therapy due to side effects $(\mathrm{n}=8)$. We analyzed in sera drawn before and after OIT specific IgA, IgG, IgG1 and IgG4 to CM, casein, betalactoglobulin and ovalbumin with enzyme linked immunosorbent assay, and IgE to CM and hen's egg white with enzymatic fluoroimmunoassay (Pharmacia CAP system).

\section{Results}

Specific IgA, IgG, IgG1 and IgG4 to CM and casein, and CM specific IgE prior to OIT were higher in children who eventually discontinued the therapy compared with children who achieved desensitization $(\mathrm{p}<0.05)$. Side effects in the entire population were associated with high IgG, IgG1, but low IgG4 levels to ovalbumin $(\mathrm{p}<0.05)$. Specific IgA, IgG, IgG1 and IgG4 to CM proteins significantly increased and IgE to CM decreased from the start to end of OIT in children who achieved desensitization $(p<0.01)$, whereas in those who interrupted OIT only IgG, IgG1 and IgG4 to CM increased significantly $(\mathrm{p}<0.03)$.

${ }^{1}$ Hospital for Children and Adolescents, University of Helsinki, Helsinki, Finland

Full list of author information is available at the end of the article

\section{Conclusions}

High specific IgE, IgA and class IgG antibodies to CM proteins appear to predict failure to achieve desensitization in CM OIT. Specific IgA and class IgG antibodies to $\mathrm{CM}$ increase and $\mathrm{CM}$ IgE decreases during desensitization.

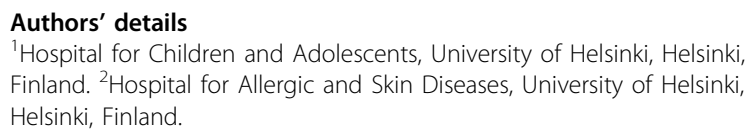

${ }^{1}$ Hospital for Children and Adolescents, University of Helsinki, Helsinki, Finland. ${ }^{2}$ Hospital for Allergic and Skin Diseases, University of Helsinki, Helsinki, Finland.

Published: 28 February 2014

doi:10.1186/2045-7022-4-S1-P27

Cite this article as: Savilahti et al:: PD27 - Specific antibodies in oral immunotherapy for cow's milk allergy: kinetics and prediction of clinical outcome. Clinical and Translational Allergy 2014 4(Suppl 1):P27.

\section{Submit your next manuscript to BioMed Central and take full advantage of: \\ - Convenient online submission \\ - Thorough peer review \\ - No space constraints or color figure charges \\ - Immediate publication on acceptance \\ - Inclusion in PubMed, CAS, Scopus and Google Scholar \\ - Research which is freely available for redistribution \\ Submit your manuscript at www.biomedcentral.com/submit}

